\title{
Caderno de poesias I
}

\section{Quatro poemas}

\author{
Alípio Correia de Franca Neto ${ }^{1}$
}

\section{SERENDIPISMO}

Uma pulsão, imperativa

como a fome ou a sede, dá início

a esta pressão coordenativa

dos dedos no teclado -- passos

que se acercam, sub-reptícios,

da caça: o seu mundo perdido,

que após um ano veio postar-se aqui como um cervo que pasce.

Um problema, não um mistério.

Você escolhe, rejeita, escolhe

de novo, como a pessoa que olhe por um binóculo e tente 
a custo regular a lente,

fixar o foco. Mas palavras

nunca sobem quando elas querem

descer, não são seus cães de caça

que você solte pra ir no encalço

da presa em meio a mil pegadas,

na água ou no interior do chão.

Não são armas com que alvejá-la,

nem armadilhas que se espalhem

de um lado e de outro. No momento em

que faço estes apontamentos,

se enganará e virá direto

aonde estou de tocaia?, ou então,

(considerando que ela é arisca

às garras e às menores iscas

da mente) a um movimento mais

brusco, partirá em disparada, sem que me reste alternativa

salvo sair atrás da presa

esquiva, e pensar no trajeto

numa forma de encurralá-la

quando estiver mais indefesa, 
sem permitir que com meus erros

seus músculos se tornem férreos,

nem que uma série de fatores --

trabalho, doenças, amores,

cansaço, festas, funerais --

neutralize o ato, e torne incerto

se ou quando ocorrerá outra vez?

Rilke disse que a vida inteira

temos dez versos a contento.

Poesia congrega vida e morte.

Ela requer reconhecer, a

cada passo, algum tropeço,

lembrar do seu estado inerme,

ou que nem sempre se está alerta.

Olhe pra trás. Desde o começo,

a sensação de espanto, lapso,

do chão cedendo sob os pés,

trazia, camuflado, em germe,

o que seria descoberto

em forma de ironia cruel:

como outro predador, mais forte, sagaz, seguiu pelo papel 
os seus sinais e movimentos;

o fez tomar uma negaça

por uma caça; e abriu em breve

este fosso, que foi coberto

de galhos e ramagens leves.

\section{A DEGRADAÇÃo DA MORTE}

No início, como parte do destino

Dos homens, toleravam-na, era aceita;

Reconhecíamos sua majestade,

Olhávamos com horror e com respeito

Quando passava, em meio a pranto e gritos,

Depois, voltávamos nossa atenção

À terra, que a presença fria dela

Instava a cultivar, nosso torrão

Herdado, nossa herança no futuro.

Era uma atividade meritória,

Um jogo, um desafio com seus perigos,

Algo que ficaria na memória.

O tempo se incumbiu de nos mostrar

Que era tapar o sol cuma peneira;

Soubemo-nos, de fato, sem aquilo

Gue não teríamos de qualquer maneira: 
Ela ainda estava à vista, só que agora

Ninguém levava mais nossa obra a sério.

A semeadura não daria frutos,

A nossa terra era uma terra estéril,

E exaustos, com aversão ao grande esforço,

À longa espera, ríamos do heroísmo;

Havia que desprezá-la, não pensar

Em nossa condição, sem consumirmos

Tempo e energia. Alguns de nós falavam,

"Ela é só isto, não sejamos tolos --

É abominável, uma coisa besta

Como uma bala perdida, um tijolo

Caindo da construção”. Outros diziam,

"Não é na calma que você não pensa

Nela. É no ruído, numa agitação

Na qual nossa existência resplandeça”.

Aos poucos a tocávamos pra longe,

Era quase invisível. Mais e mais

Ficava a cargo dos especialistas,

Era esquecida dentro de hospitais,

De guetos geriátricos, e a dor

Da perda, esta era explicada em termos

De problemas de personalidade --

Ou então proliferava, noutro extremo, 
Em forma de imagem, gerada e extinta

Num gesto idêntico, sem susbstância

E despertando uma emoção fugaz

Em nós -- a imagem de outros, a distância,

Uma multidão sem nome e atordoante

Tragada pelo transe universal --

Um espetáculo de rua, cheio

De estrondos, de clarões e sem final.

Quando ela pareceu irreal, e o tempo

Não teve mais coesão, capitulamos

A um sono fundo e breve à noite. $\mathrm{O}$ sol

Voltou, com o mesmo dia. E despertamos.

\section{BRIGA DE MADRUGADA}

Berros, e no meio da noite cada um desperta Imediatamente num estado de alerta,

"Eu pago a porra desse aluguel!", grita a voz

De alguém jovem, que repercute pelo poço

Do prédio. Persianas são fechadas com força.

"Eu te ajudei!", irrompe a voz de um velho; após

Segundos de silêncio, de outro apartamento

Vem o "Olha esse barulho!"; num baque violento,

Bate uma porta; "abre essa merda!"; alguém dá socos

Ou chutes nela; "deixa a minha filha em paz!",

Diz, trêmula, a voz de uma velha, ao que o rapaz

Retruca, "cala a tua boca! Vocês são uns loucos, 
E a filha de vocês não presta!"; então se escuta o Velho, "repete o que você falou, seu puto!", E a comoção de ruídos surdos, de gemidos E imprecações, a voz de uma criança com um "ai!" Que se dissolve em choro, alguém gritando "pai!" Com horror, móveis caindo, um vidro que é partido --

Tudo como se alguma força natural

De repulsão, tão autônoma quanto um mal, Não só os desagregasse entre si, uma espécie

De morte, mas os separasse num segundo Do prédio, da rua, da cidade, do mundo, De tal maneira, que nada mais ali viesse

A não ser deles. E enquanto em ponto distante Gente ainda mais estranha se prosterna diante De estrelas de um destino, o corpo de bombeiros Que chega com a sirene e pára no local Traz só uma verdade poética incidental Aos que queimam na fogueira do desespero.

\section{O LEITOR}

em louvor de James Joyce

Dizia, sou um homem sem imaginação, procuro alguma coisa e a encontro no caminho.

A espécie de arte que almejava carecia de um sustentáculo anterior à criação. 
Como o hermeneuta, o jesuíta afeito a técnicas diversas de leitura, anos a fio rastreou, das Escrituras até os livros seculares, as formas que a palavra escrita havia assumido --

ele tinha ânsia de entender, cada vez mais, pela leitura, o que era ler; de perscrutar as semelhanças entre um texto, que se trama na língua, e a vida da pessoa, que se trama

na experiência - sem jamais ignorar que os termos, como quem os utiliza, são falíveis: podia usar até dos mais antigos, só não podia ter o mesmo sentimento.

Desde jovem, já parecia inevitável que sua disposição, tão apta a encarar verdades quase intoleráveis, levaria o homem que ele era a entrar em guerra contra o artista

que ele era, e impediria de fechar os olhos para qualquer limite da energia humana: nunca prometeria, nunca esperaria que fosse eterna a vassalagem das palavras,

da mesma forma, não podia acreditar que a lealdade de amigos durasse pra sempre, nem servir as coisas em que havia perdido a fé -- terra natal, família, igreja - nem 
sequer satisfazer a fome de si mesmo

com pedras frias. Sabia que cada um escolhe

o seu quinhão de sofrimento, o seu destino;

devia incorrer no débito da coisa feita,

não permitir inquietações quanto ao futuro, eram um desrespeito ao momento presente,

o ponto em que a vida por vir deságua e vira passado. Uma província, imersa na mais triste

paralisia da existência, era matéria sólida, boa pra se erguer uma morada pros ideais - palco da peça em que cada um tem um papel. Tudo o que tinha, e o que buscava,

estava lá; era preciso paciência, segurança, ter a alma satisfeita, a fim de olhar para essas coisas, as desentranhar e reencarnar. Assim, com as armas que ele tinha-

silêncio, exílio, astúcia -- leu cidades, ruas, rios e paisagens, pessoas, sonhos, a memória, o cotidiano caótico e os padrões da história, leu essas coisas como páginas de um livro;

e lê-las desse modo equivalia a achar uma consciência incriada - e um prazer tão maduro quanto a piedade pelos outros, o pendor para culpar o mundo sem culpar ninguém. 
Aquele apóstata tinha outra fé, de que a poesia ou a arte nos ajudavam a compreender onde estamos em nossa situação dedálica, de imagens desconexas, da infância à velhice

sem ver sentido na jornada, sem um pai pra nos mostrar qual a tarefa, qual a ação mais adequada pra ela -- e estava convencido de que ninguém se perde tanto quanto aquele

que não vê além do próprio umbigo, e indiferente ao diálogo de namorados no cair da noite, parecendo um salmo, ou ao órgão da igreja no Largo Santa Cecília ecoando

irresistivelmente real, não se dá conta de algo se destacando do plano de fundo, auto-suficiente - uma mulher, com uma ginga, um quê feito pra se degustar com a língua --

o momento radiante, fugaz, parecido com brasas se apagando, quando, numa esquina que perdeu seu sentido habitual, uns olhos, pelo encantamento do coração, nos lêem.

${ }^{1}$ Poeta, tradutor e doutorando em Teoria Literária e Literatura Comparada na Universidade de São Paulo, com o projeto "A Balada do Velho Marinheiro como representação artística da revery dos românticos". "Quatro poemas" fazem parte do livro Amigos de Infância, a ser lançado pela Editora Iluminuras. 